\title{
Does Improved Water Productivity Matter for the Farmers? A Case of Water-Efficient Rice Production from Pakistan
}

\author{
Dr. Jawad Ali \\ Helvetas Swiss Inter-cooperation Pakistan \\ G-6/1-1, Islamabad, Pakistan \\ Dr. Muhammad Zulfiqar* \\ The University of Agriculture, Peshawar, Pakistan \\ Dr. Arjumand Nizami \\ Helvetas Swiss Inter-cooperation Pakistan \\ G-6/1-1, Islamabad, Pakistan
}

\begin{abstract}
:
Rice is an important crop of Pakistan being the third most important export commodity in agriculture sector earning large revenues. This study was conducted with the rice farmers collaborating with Water Productivity project in Sheikhupura district in Pakistan. The study presents a comparison between the findings from a baseline study conducted in early 2017 and end 2018 based on 21 farmers selected from head, mid and tail of water channels. The objective of the analysis was to assess the economic impact of adopting improved irrigation practices and other related agronomic practices to increase water productivity. Two cropping seasons were compared between 2017 and 2018 based on economic returns from improved rice production practices. The data were collected through focus group discussions, individual interviews, and field evidences of use of technology and costs incurred and registered. The analysis is based on per acre inputs and output of paddy crop. The analysis shows that the net per acre revenue received by farmers significantly increased. The increase in revenue is mainly attributed to efficient irrigation practices and adoption of co-related better agronomic practices. The results prove economic viability of water efficient techniques and agronomic practices. The study also documents the effectiveness of public-private partnership aspects which served as a driving force for adoption of water productive approach.
\end{abstract}

Keywords: Paddy; Rice; Water Productivity; Water Economics; Pakistan; Business Case

DOI: $10.7176 / \mathrm{DCS} / 9-9-07$

Publication date:September $30^{\text {th }} 2019$

\section{Introduction}

Rice is an important crop of Pakistan. It occupies more than 2.9 million hectares in 2018, only behind wheat and cotton in the country. The rice production recorded in 2018 was 7.45 million tons (GoP 2018). Rice accounted for $3 \%$ value addition in agriculture sector and contributed $0.6 \%$ to the country's GDP in 2016-17 (GoP 2017). The area under rice and rice productivity per hectare has increased over the years. The area under rice, its production, and yield over the last 11 years are given in Table-1.

Rice is produced all over Pakistan, however, Punjab occupies the largest share with about $63.47 \%$ of the total rice area in Pakistan. Sindh follows with around 28.56\% area. Balochistan and KP respectively occupy 5.85\% and $2.12 \%$ area in 2017-18 (GoP 2018). Rice is not only an important staple food crop of Pakistan; it is also an important export commodity earning precious foreign exchange for the country. In the year 2015-16, the rice export earned more than US\$1376 million (GoP 2017).

The productivity of rice depends upon the nature of production technology including irrigation water application and agronom

c practices. Compared to other cereal crops, rice is known as a high delta crop consuming a lot of water. The global average to produce one $\mathrm{Kg}$ of paddy rice is 3400 liters of water (Hoekstra 2008) that reflects water intensity of rice crop. However, Claro (2019) argued that traditional rice production requires irrigation water in the range of 300 to 500 liter only, for producing one $\mathrm{Kg}$ of paddy rice. The International Rice Research Institute (IRRI) stated that rice takes an average of 1,432 liters of evapo-transpired water to produce $1 \mathrm{Kg}$ of coarse rice (IRRI, 2010). Bauman (2008) stated that some studies carried out at the IRRI have shown that rice plants growing under a range of water applications transpired 500-1,000 liters of water to produced $1 \mathrm{Kg}$ of coarse rice.

The current way of growing irrigated rice in most Asian farms requires large amounts of water. For example, in India and the Philippines an average of about 3000 liters of water is used to produce $1 \mathrm{Kg}$ of rice. The increasing shortage of water in irrigated areas because of, for example, the lack of water conservation practices and competing demand for water from the industrial, domestic and other non-agriculture sectors, show that the present rice cultivation techniques need better water management and agronomic practices (IRRI, 2018). Kumar (2014) argued that in case of India, farmers need to produce 50\% more grain by 2020 to meet its demand. As per CCAFS (2013), 
for enhancing food production under changing climatic conditions there is a need for reorientation of agriculture to climate smart production techniques from current practices. Zulfiqar, et al. (2018) reported that with increasing climate variability and rapid melting of glaciers, water scarcity is expected to be a major challenge to agricultural production and food security in Pakistan. Therefore, improved water productivity in agriculture is even more urgent in Pakistan.

Beside water, land preparation and agronomic practices are equally important in determining rice productivity and quality. Precision land leveling (e.g. through laser technology) as part of land preparation for rice crop alone can reduce irrigation time by 47 to 69 hours per hectare per season including yield improvement by around $7 \%$ as argued by Aryal et al. (2015). Sowing good quality seeds leads to lower seed rate, better germination, more uniformity, less replanting, and vigorous early growth which help to increase resistance to insects and diseases and decrease weeds. As a result, yield can increase by 5-20\% (Knowledge Bank 2018).

In traditional rice production system, the diseases and insect attacks coupled with weeds infestation could reduce rice yield by 40-45\% (Technology Time 2018). Therefore, pest and disease prevention and control as well as weeds management in rice fields are important. Harvesting time with reference to rice moisture content is very important. Premature cutting of rice keeps the grain from reaching maturity and may cause serious losses in the quality of the product. Furthermore, immature grains, due to too early harvesting, result in high percentage of broken and low milling recovery. Maximum head rice recovery was obtained when the paddy crop was harvested at moisture content ranging from 20-30\% (Ahmad et al. 2016).

In order to address farmers' needs to save water, energy and fuel in irrigated rice, the IRRI has developed the Alternate Wetting and Drying technology, a water-saving technology. The lowland (paddy) rice farmers can apply to reduce their water use in irrigated fields. In AWD, irrigation water is applied to flood the field a certain number of days after the disappearance of ponded water. The number of days of non-flooded soil in AWD between irrigations can vary from 1 day to more than 10 days. The threshold of $15 \mathrm{~cm}$ water depth (below the surface) before irrigation is called "Safe AWD" since this will not cause any yield decline. In Safe AWD, water savings are in the order of 15.0- 30.0 percent.

Data for this study was taken from the Water Productivity (WAPRO) project area in district Sheikhupura of Punjab province in Pakistan. The WAPRO project is jointly implemented by HELVETAS Swiss Intercooperation (Helvetas), a local company called Rice Partners Limited and an international company Mars Foods Netherlands. It is being financed by Global Programme Food Security, Swiss Agency for Development and Cooperation (GPFSSDC) and the private companies involved. WAPRO has introduced an innovative approach to increase water productivity through Push-Pull-Policy approach. Within the PUSH component new production technologies are introduced to the participating smallholder farmers that reduce irrigation demand while increasing crop yields. PULL component consists of ensuring purchase of rice produced by the farmers by private companies which motivates them to implement water saving technologies. Policy looks into causal analysis of why farmers do not apply water productive technologies, analyze options and evidence of improvements, and communicate for further uptake.

This study was conducted with an aim to determine the profitability of rice production as a result of adopting water saving techniques coupled with better agronomics practices by the beneficiary farmers supported under public-private partners. It is based on comparing practices in pre and post scenario by analysing per acre revenue generated by rice farmers ${ }^{1}$.

\section{Material and Methods}

The study was conducted in three selected villages of tehsil Muridke of Sheikhupura, namely Joyianwala, Saikhum and Kathianwala. The Focused Group Discussions (FGDs) and individual interviews of 21 selected rice producers were conducted in September 2017 as a baseline data and in December 2018 after adoption of improved water and agronomic interventions. The target rice producers were the same farmers both the times located at head, mid and tails of the channels for uniformity and quality of data for comparison. The individual interviews of 21 farmers were carried on the channels in a way that 7 farmers each were interviewed at head, middle and tail of the channels. Farmers' own feedback and analysis on change of practices has been accounted for in this study beside factual data on revenues provided by the farmers.

The farmers interviewed are those who adopted precision land leveling, Alternate Wetting and Drying (AWD) tubes technology, and advisory services on improved agronomic practices through WAPRO project partners including international and local companies with also an active advice of government agriculture extension services. The analysis is mainly based on inputs applied for the production of rice crop including land rent and output of paddy rice and paddy stalks. The analysis is based on the market-based per acre prices of the inputs and output. In addition to the farmers, the staff of the Rice Partners' Limited (who buy rice from the farmers) were also interviewed for triangulation of information. The data collected were analyzed using MS-Excel for

\footnotetext{
${ }^{1} 1$ acre is equal to 0.405 hectare.
} 
quantitative analysis while other information was analyzed qualitatively.

The net return per acre was estimated using the following equation:

$\mathrm{NR}=\mathrm{GR}-\mathrm{TC}$

Where

- NR is Net Return gained from the production of paddy rice in Pak Rupees.

- GR is the Gross Revenue computed by multiplying the paddy and stalk quantity produced with the prices of paddy rice and rice stalk received by the produce respectively.

- $\quad \mathrm{TC}$ is the sum of the variable cost i.e. cost of inputs used and fixed rental value of land reported by the farmers.

The details of cost variables were collected for the analysis as per followings:

Land preparation and cultivation

The following inputs are used for land preparation and cultivation:

a. Rotavator (Dry Ploughing)

A rotavator is a useful piece of machinery for soil preparation. This versatile piece of farming equipment is a motorized machine which uses rotating blades to turn soil. Dry ploughing is done for 3 to 4 times.

\section{b. Disc ploughing (Dry Ploughing)}

The disc plough is designed to work in all types of soil for functions such as soil breaking, raising, turning and mixing. Disc ploughing is conducted for 1 to 2 times. The farmers however mostly prefer rotavator for dry ploughing.

c. Dry Planking

Planking is done to crush the hard clods to smoothen the soil surface and to compact the soil lightly. Thus, the field becomes ready for sowing after ploughing by harrowing and planking.

\section{d. Laser Land Leveling (LLL)}

Laser Land Leveling is a process of precision leveling smoothening the land surface from its average elevation with a certain degree of desired slope using a guided laser beam throughout the field. It has two major benefits: one, improving water productivity, and two, increased effective area under crop within per unit area. It is done once in 2 or 3 years.

e. Wet ploughing \& Wet planking

The wet ploughing and planking are done to plough and level the land in wet conditions. Wet ploughing is done at least twice, whereas wet planking is done just once.

\section{Seed and Seed Treatment}

The seed rate applied is $1 \mathrm{Kg}$ per acre at head and middle whereas $1.2 \mathrm{Kg}$ per acre ${ }^{1}$ at the tail. A higher seed rate is preferred by the farmers at the tail to secure losses due to failed germination. The seed is treated to secure viability of seed.

\section{Transplantation}

Rice is first sown in the nursery fields to prepare seedings. These seedlings are then transported to the rice fields and are transplanted by specialised labour (mostly women) to raise rice crop.

\section{Fertilizers Application}

a. Di-Ammonium Phosphate (DAP)

DAP is used by all farmers in the production process of rice. However, in case farmyard manure is available and applied, the DAP application is adjusted accordingly.

b. Urea

Urea fertilizer is also used by all the farmers in the production process of rice. Usually 1 bag of $50 \mathrm{~kg}$ is applied per acre.

c. Zinc

As a result of advisory services from WAPRO, the farmers are now applying Zinc to their rice crop to improve its nutritional quality. A recommended dose of 2 bags of $3 \mathrm{Kg}$ each is applied per acres. However, at the tail end, some of the farmers also choose to use 1 bag per acre.

d. Farmyard manure (FYM)

Farmers possessing livestock mostly choose to apply FYM. In case of adequate availability of FYM, the application of chemical fertilizer is reduced accordingly to supplement fertilizer requirement for the crop. On an average, $100 \mathrm{~kg}$ application has been recorded per acre.

Plant protection measures

a. Weedicides and Pesticides are applied depending upon the nature and severity level of diseases and pests attack on rice crop.

\footnotetext{
${ }^{1}$ Tail farmers apply higher seed rate to cover the risk of failed germination.
} 


\section{Irrigation}

There are three types of costs involved for irrigating the fields:

Pumping of groundwater: This is the cost incurred for running tube wells to pump groundwater. The canal water availability reported at head was 75 to $80 \%$ of requirement and the rest of the need was met through tube well operation. The farmers at middle of the channel were also better off as they were able to get around $50 \%$ of irrigation water requirements out of canal water and the rest from the tube well. However, the situation at the tail end was wretched. They received very little quantity of water, averaging $20 \%$, from canal to irrigate their rice crop. Thus, they mostly depended on tube wells to irrigate their lands under rice crop.

Irrigation application costs: Although irrigation is a daunting task and requires special supervision, it was reported that no specific labour hours were used for irrigating the fields. The labour hired on monthly or daily basis during rice growing season was used also for supervising irrigation activity along with other activities. Hence part of the crop supervision cost may be attributed to supervising irrigation.

Water charges (Abiana): The farmers pay water charges to the representative of Government's Irrigation

Labour Department on per acre basis.

At least one multi-purpose labour is engaged on the basis of monthly salary for every 10 acres rice area Land (fixed input) on an average. Farm owners also hire labour on daily wages on need basis.

\section{Harvesting}

The prevailing land rent has been taken as fixed input cost per acre.

\section{Transportation}

The respondent farmers are using combined harvesters to harvest their paddy. Several combined harvester units are available in the market during rice harvesting season on competitive rates.

All the farmers selected for the study are now the contract farmers of RPL. They sell their rice to RPL subject to specified range of moisture contents. The transportation costs to fetch rice to RPL gate was also paid by RPL. However, for the purpose of analysis and keeping in view the short-term transportation support from RPL, transportation cost has been included. Such a cost from farm to market may slightly

\section{Output - The Crop}

vary from location to location. An average per $40 \mathrm{Kg}$ cost has been taken for the purpose of analysis.

There are mainly two types of products i.e. paddy rice in $\mathrm{Kg}$, and rice stalks from rice residue. The prices annually fluctuate in the market. Only market prices have been considered in this analysis even though RPL pays certain premium to its contract farmers.

\section{Results and Discussions}

The analysis reveals that as a result of project advisory services, the farmers have changed their farming practices from traditional to more enterprise oriented. They started optimum input use and other agronomic practices along with water productivity techniques. These practices have actually increased the cost of rice crop per acre as reflected in table 2. The increase is cost is attributed to use of technology (e.g. laser and AWD tubes), application of fertilisers, improved soil preparation and supervision. The net increase in cost of rice production per acre over the baseline is Pak Rs.15,453 at head, Rs.15,804 at middle and Rs.13,509 at the tail of the water channels. The Figures-2 show graphic presentations of pre and post practices comparison for cost positions of the rice farmers:

The farmers at the head of the water channel have increased their cost from Pak Rs.45,749 to Rs.61,202 per acre, whereas farmers at the middle of the water channel have increased their cost from Rs.47,949 to Rs.63,753 per acre. The tail end farmers' cost of production increased from Rs.51,209 to Rs.64,718 per acre. Figures-1 shows graphic presentations of pre and post practices comparison on cost of rice production per care:

The analysis of revenue shows that the farmers after adopting improved practices, including optimum input use and other agronomic practices along with water productivity techniques, have generated more revenue from rice crop per acre. The difference is shown in Table-3.

The increase in gross revenue per acre over the baseline is Pak Rs.26,875 at head, Rs.24,450 at middle and Rs.17,950 at the tail of the water channels. The Figures-2-3 show graphic presentations of pre and post practices comparison for revenues and net revenue positions of the rice farmers:

The farmers at the head of the water channel have increased their net revenue from Pak Rs.9,376 to Rs.20,798 per acre, whereas farmers at the middle of the water channel improved their net revenue from Rs.5,601 to Rs.14,247 per acre. The tail end farmers increased their net revenue from Rs.2,341 to Rs.6,782 per acre. The rice farmers at the head of the water channel gained a higher return of Rs.11,422 per acre on account of adopting improved practices in rice cultivation. The figure further shows that the farmers from middle and tail of the water channels improved their net revenue per acre by Rs.8,646 and Rs.4,441respectively as a result of adopting improved practices. 
The analysis based on data collected from individual rice growers was cross-checked with the information gathered through focus group discussions during the field investigations. The farmers reported that as a result of experts' services in the field to cultivate rice with less water (through laser land leveling, AWD technology) and improved agronomic practices (timely application of fertilizers, weedicides, pesticides, zinc application, maintaining appropriate moisture content of paddy at harvesting) improved productivity and quality of rice. By adhering to appropriate moisture contents at harvesting time, the sample farmers ensured minimum rejection of their crop by the purchasers and better price was fetched compared to the past. The respondents informed that use of less irrigation water compared to traditional irrigation practices had positive affect on the crop yield with reduced cost.

\section{Conclusion and Recommendations}

Rice is an important crop of Pakistan accounting for 3\% value addition in agriculture sector and $0.6 \%$ or more contribution to the country's GDP (2016-17). Rice is not only an important staple food crop of Pakistan. It is also an export commodity earning precious foreign exchange for the country. In the year 2015-16, the rice export earned more than US\$1376 million. Although true for every agricultural crop, the productivity of rice depends upon the nature of agronomic production technology but more critically on security of irrigation water application. Compared to other cereal crops, rice has a much higher water consumption which invites an overall national debate if rice is the right crop for Pakistan that is already suffering water scarcity and climate stress. Therefore, in order to prevent rice being eliminated from agricultural system of the country, it is important to explore ways and means to cultivate rice with water efficient techniques. For the farmers unfortunately, an environmental argument or a potentially dooms' scenario is not enough to convince on this change. They need to see the difference in their revenue in order to believe that saving water can turn into more revenue.

The study revealed that the farmers after adopting efficient irrigation techniques and related improved agronomic practices significantly gained in terms of output and income. The figures show that the farmers improved their net revenue per acre by Pak Rs.11,422, Rs.8,646 and Rs.4,441 at head, middle and tail of water channels respectively as a result of adopting project advocated rice production technology. As a whole, farmers from up, mid and tail of the channel received 122\%, 154\% and 190\% higher return compared to the baseline which suggests that saving water had a greater economic impact for tail end and mid channel farmers. The 21 farmers included in this analysis cultivated rice on an area of 598 acres. The overall increase in the household economy of 21 farmers, over the baseline, tunes to more than Rs.10 million during rice season of 2018 .

The result of the study proves economic viability of water efficient techniques and agronomic practices. These results build a good business case for up scaling for the benefit of rice farmers and economic return for the government as a whole since rice is an important revenue generation crop for the country. In addition, the results also support the role of private sector in achieving water productivity by supplementing government efforts to have more crop cultivated with limited resources. Few companies may have thought of risks to their businesses posed by growing water scarcity in Pakistan. Corporates are generally unaware of both risks related to dwindling freshwater and the approaches for effective management of available water for sustainability of their businesses. Yet, the fact remains that water scarcity already poses serious challenges to supply chains if the current trends continue. The role of business sector in water management is increasingly being recognized by policy makers because water challenges are too complex for governments to solve alone. A motivated private sector is absolutely essential to achieve water efficiency by providing conditional support to the farmers in supply chains. This is possible mainly by using economic argument for water efficiency. This implies that farmers need to see a business case (costs and returns) in adopting overall cultivation practices including water use efficiency since otherwise water is a free commodity in Pakistan. Farmers and companies' participation are crucial to lend a hand in ensuring access to resource by maximum number of farmers.

\section{Acknowledgment}

This study is financed by the Water Productivity project being financed by the Global Programme Food Security of the Swiss Agency for Development and Cooperation (GPFS-SDC) and jointly implemented by Helvetas Swiss Intercooperation, Rice Partners Limited Pakistan and Mars Food Netherlands. The authors are thankful to Imran Sheikh and Zafar Iqbal of Rice Partners' Limited for providing very useful information and coordination support during data collection. The authors are also thankful to the 21 rice producing farmers who provided data and very useful information regarding rice production, adaptation of water efficient technology and rice yields. 
Table-1: Area, Production and Yield of Rice (2007-08 to 2017-18)

\begin{tabular}{|c|c|r|r|}
\hline Year & Area (Ha) & Production (tons) & Yield (Kg/ha) \\
\hline $2007-08$ & $2,515,400$ & $5,563,400$ & 2,212 \\
\hline $2008-09$ & $2,962,600$ & $6,952,000$ & 2,347 \\
\hline $2009-10$ & $2,883,100$ & $6,882,700$ & 2,387 \\
\hline $2010-11$ & $2,365,300$ & $4,823,300$ & 2,039 \\
\hline $2011-12$ & $2,571,200$ & $6,160,400$ & 2,396 \\
\hline $2012-13$ & $2,308,800$ & $5,535,900$ & 2,398 \\
\hline $2013-14$ & $2,789,200$ & $6,798,100$ & 2,437 \\
\hline $2014-15$ & $2,890,600$ & $7,002,800$ & 2,423 \\
\hline $2015-16$ & $2,739,500$ & $6,801,600$ & 2,483 \\
\hline $2016-17$ & $2,724,000$ & $6,849,300$ & 2,514 \\
\hline $2017-18$ & $2,900,000$ & $7,449,800$ & 2,569 \\
\hline
\end{tabular}

Source: Agriculture Statistics of Pakistan 2017-18, Bureau of Statistics, Government of Pakistan.

Table 2: Comparison of Cost per acre at Head, Middle and Tail ${ }^{1}$

\begin{tabular}{|l|c|c|c|}
\hline \multirow{2}{*}{ Location at Channel } & \multicolumn{2}{|c|}{ Cost per acre (Rs.) } & \multirow{2}{*}{ Increase (Rs.) } \\
\cline { 2 - 4 } & Pre Project & Post Project & 15453 \\
\hline Head & 45749 & 61202 & 15804 \\
\hline Middle & 47949 & 63753 & 13509 \\
\hline Tail & 51209 & 64718 & \\
\hline Overall & & & \\
\hline
\end{tabular}

Source: Field data 2017-2018

Table 3: Comparison of Gross Revenue per acre at Head, Middle and Tail

\begin{tabular}{|l|c|c|c|}
\hline \multirow{2}{*}{ Location at Channel } & \multicolumn{2}{|c|}{ Revenue per acre (Rs.) } & \multirow{2}{*}{ Increase (Rs.) } \\
\cline { 2 - 3 } & Pre Project & Post Project & 26875 \\
\hline Head & 55125 & 82000 & 24450 \\
\hline Middle & 53550 & 78000 & 17950 \\
\hline Tail & 53550 & 71500 & \\
\hline Overall & & & \\
\hline
\end{tabular}

Source: Field data 2017-2018

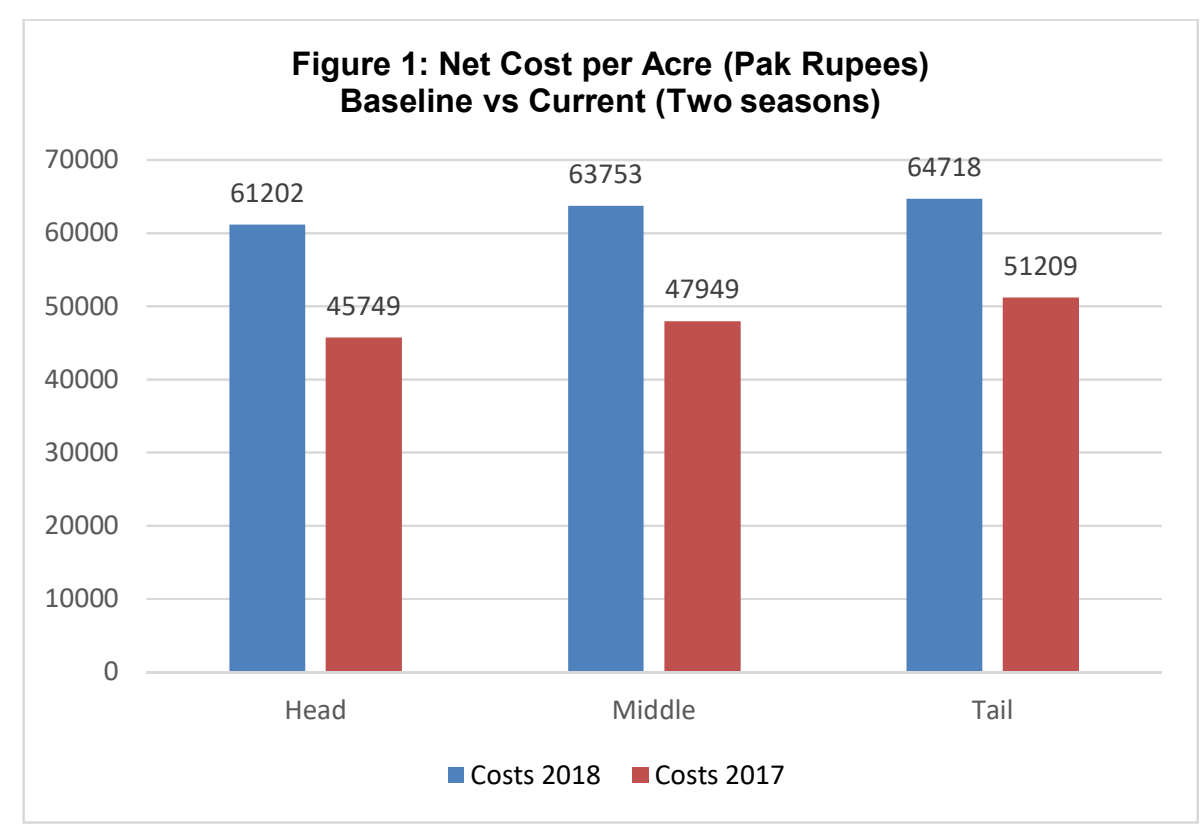

\footnotetext{
${ }^{1}$ For currency reference, 1 USD = 138 Pak Rupees. 1 Euro = 157 Pak Rupees in 2018.
} 
Figure 2: Net Revenue per Acre (Pak Rupees)

Baseline vs Current (Two seasons)
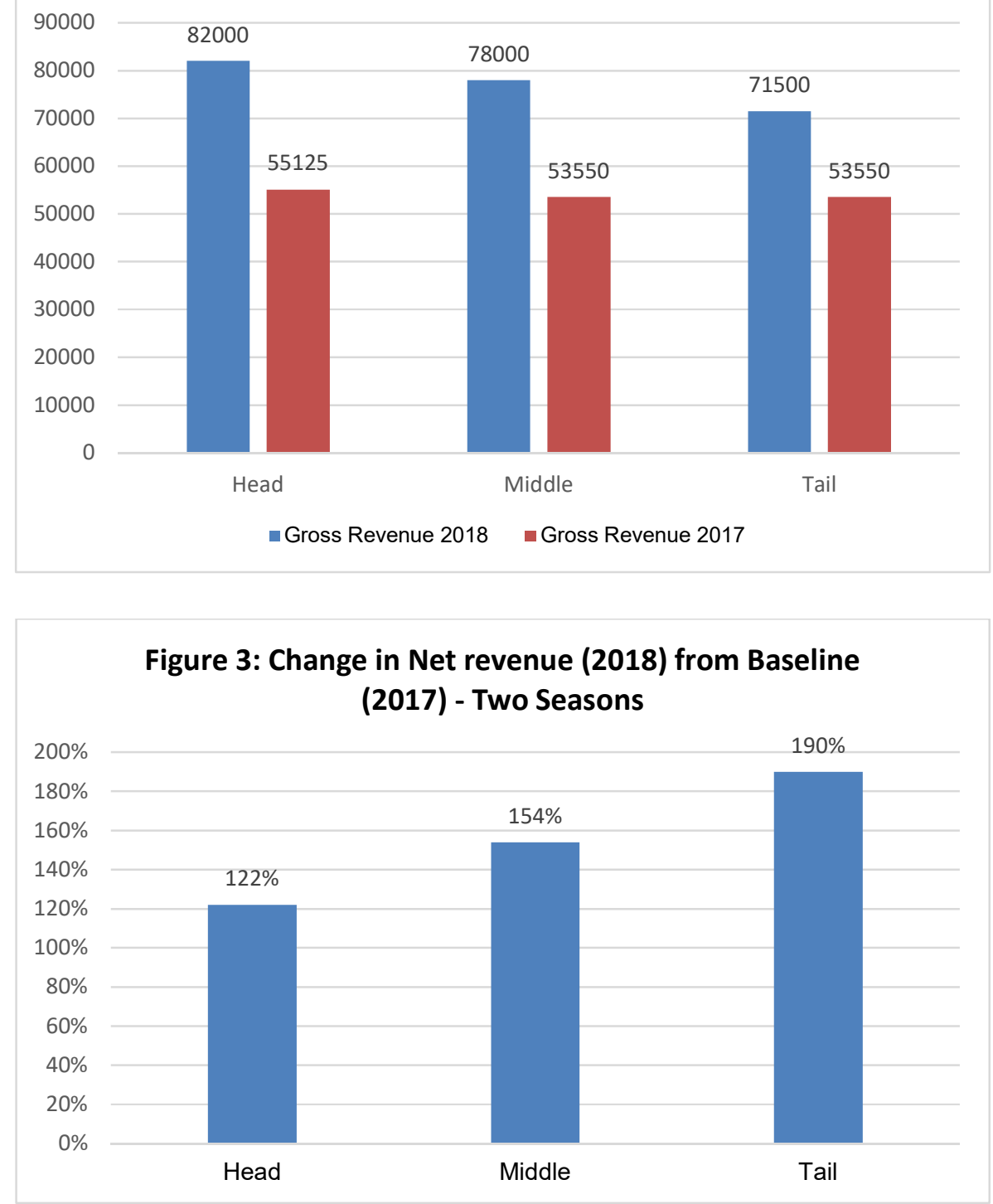

\section{References}

Ahmad, T. et al. (2016). Effect of Paddy Harvesting Methods on Rice Quality and Head Rice Recovery. ARPN Journal of Engineering and Applied Sciences, 11(24). www.arpnjournals.com

Ali, A., Clyma, W. and Early, A.C. 1975. The improved water and land use management through precision land leveling. In: Journal of Water Management. 1991.

Aryal et al. (2015). Impacts of laser land leveling in rice-wheat systems of the north-western indo-gangetic plains of India. Food Security 7(3) DOI: 10.1007/s12571-015-0460-y.

Bouman, B. (2008). http://www.knowledgebank.irri.org/ewatermgt/ courses/course1/ modules/ module01/Additional\%20info\%20for\%20M1L5.pdf

CCAFS. (2013) Big Facts on Climate Change, Agriculture and Food Security. Copenhagen, Denmark: CGIAR Research Programme on Climate Change, Agriculture and Food Security (CCAFS).

CLARO https://claroenergy.in/5-most-water-intensive-crops/

GoP (2017). Pakistan Economic Survey 2016-17, Economic Adviser's Wing, Finance Division, Government of Pakistan, Islamabad.

GoP (2018). Agriculture Statistics of Pakistan 2017-18, Economic Wing, Ministry of National Food Security and Research, Government of Pakistan, Islamabad. 
Hasan, K. et el. (2016). Impact of Alternate Wetting and Drying Technique on Rice Production in the Drought Prone Areas of Bangladesh. Indian Res. J. Ext. Edu. 16 (1) 39-48.

Helvetas (2018). https://www.helvetas.org/en/switzerland/what-we-do/how-we-work/ourprojects/global/ waterproductivity-WAPRO. Helvetas Swiss Intercooperation, Switzerland.

Hoekstra, A.Y. (2008). The Water Footprint of Food. In: Fbrare, J. (ed.) Water for food. The Swedish Research Council for Environment, Agricultural Sciences and Spatial Planning (Formas), Stockholm.

IRRI (2010). Rice Knowledge Bank. http://www.knowledgebank.irri.org/watermanagement

IRRI (2018). Module 3, Water Management. http://www.knowledgebank.irri.org/ ericeproduction/ III.1 Water usage in rice.htm

Jat, M.L., Pal, S.S., Subba Rao, A.V.M. and Sharma, S.K. 2003. Improving resource use efficiency in wheat through laser land leveling in an ustochrept of Indo-Gangetic plain. In: National Seminar on Developments in Soil Science, 68th Annual Convention of the Indian Society of Soil Science, November 4-8, 2003, CSAUAT, Kanpur (UP), India.

Khattak, J.K., Larsen, K.E., Rashid, A. Khattak, R.A. and Khan, S.U. 1981. Effect of land leveling and irrigation on wheat yield. Journal of AMA. 12: 11-14.

Knowledge Bank (2018). Seed quality - IRRI Rice Knowledge Bank www.knowledgebank. irri.org/step-by-stepproduction/pre-planting/seed-quality

Kumar R, Gautam HR.(2014). Climate change and its impact on agricultural productivity in India. Journal of Climatology and Weather Forecasting. 2:109. DOI: 10.4172/2332-2594.1000109.

Rejesus. R.M. et el. (2010). Impact of the alternate wetting and drying (AWD) water-saving irrigation technique: Evidence from rice producers in the Philippines. Food Policy 36(2011) 280-288.

Sattar, A., Khan. F.H. and Tahir, A.R. 2003. Impact of precision land leveling on water saving and drainage requirement. J. AMA. 34: 39-41.

Technology Time (2018). https://www.technologytimes.pk/ production-technology-rice/.

Zulfiqar, M. et al (2018): Threats of Global Warming for Pakistan's Agriculture - Evidence from Shigari Kalan Watershed Skardu. Sarhad Journal of Agriculture. 34(3): 569-574. 